\author{
E. Radziemska ${ }^{1}$, T. Seramak ${ }^{2}$, P. Ostrowski $^{1}$ \\ Gdansk University of Technology, ${ }^{1}$ Chemical Faculty, ${ }^{2}$ Mechanical Faculty, 80-952 \\ Gdansk, Narutowicza 11/12, Poland
}

\title{
PURE SILICON RECOVERING FROM PHOTOVOLTAIC MODULES
}

\begin{abstract}
Photovoltaic technology is worldwide used to provide reliable and cost-effective electricity for industrial, commercial, residential and community applications. The average lifetime of PV modules can be expected to be more than 25 years. The disposal of PV systems will emerge as a problem, considering the still increasing production of PV modules. Recycling of such modules can be done at about the same cost level as its disposal. Recovering the pure silicon from damaged or end-of-life PV modules can lead to economical and environmental benefit. Chemical treatment conditions need to be precisely adjusted in order to achieve the required purity level of the recovered silicon. For crystalline silicon based PV systems, a series of etching processes has been carried out as follows: electric connectors (etching or removing), ARC and n-p junction etching. The chemistry of etching solutions was individually adjusted for the different silicon cell types. Efforts were taken in order to formulate a universal composition of etching solution.
\end{abstract}

Key words: silicon, recycling, photovoltaic cells, etching, renewable energy sources

\section{INTRODUCTION}

Crystalline silicon photovoltaic cells are produced as silicon plates of $200 \div 500 \mu \mathrm{m}$ thickness and dimensions of: $100^{\mathrm{x}} 100 \mathrm{~mm}^{2}, 125^{\mathrm{x}} 125 \mathrm{~mm}^{2}$ or $150^{\mathrm{x}} 150 \mathrm{~mm}^{2}$. In the first step of the PV cell manufacturing, on the frontal surface of these plates, by the process of atomic diffusion of phosphorus, an $n-p$ junction is created and then, on this layer an anti-reflective coating (ARC) is applied. In the next step of the manufacturing process, two electrodes made of aluminum and/or silver paste are created on the plate's front and back side [1].

The PV module manufacturing process involves laminating single cells after forming of $\mathrm{n}-\mathrm{p}$ junction connector layer and fastening them in the frame made of aluminum. The recycling process requires disassembling the modules according to the flow chart presented on Fig.1. A thermal process allowing fast, simple and economically efficient module disassembling is the first stage of PV module recycling. The primary process carried out during PV module recycling is the solar cell chemical treatment. In order to re-acquire the silicon powder or plates for its use in the new photovoltaic cell manufacturing, the remove of metal electrodes, AR coating and n-p junction layer is 
required. These operations may be performed by dissolving in acid or alkaline based solutions.

The metallization is removed by a sequence of etching. The backside metallization of older solar cells often contains silver. During this process step, the silver is dissolved. From the waste acids, the silver can be recovered by electrolysis. Profit of silver recycling with different metal concentrations in the acid and different silver prices was analyzed by Müller et al. [7].

Recovered silicon could be utilized as: the raw material in the photovoltaic industry, the addition to alloy steel, changing their mechanical properties (hardness, tensile strength, impact strength) and as the material for ceramics, based on non-metal powders manufacturing.

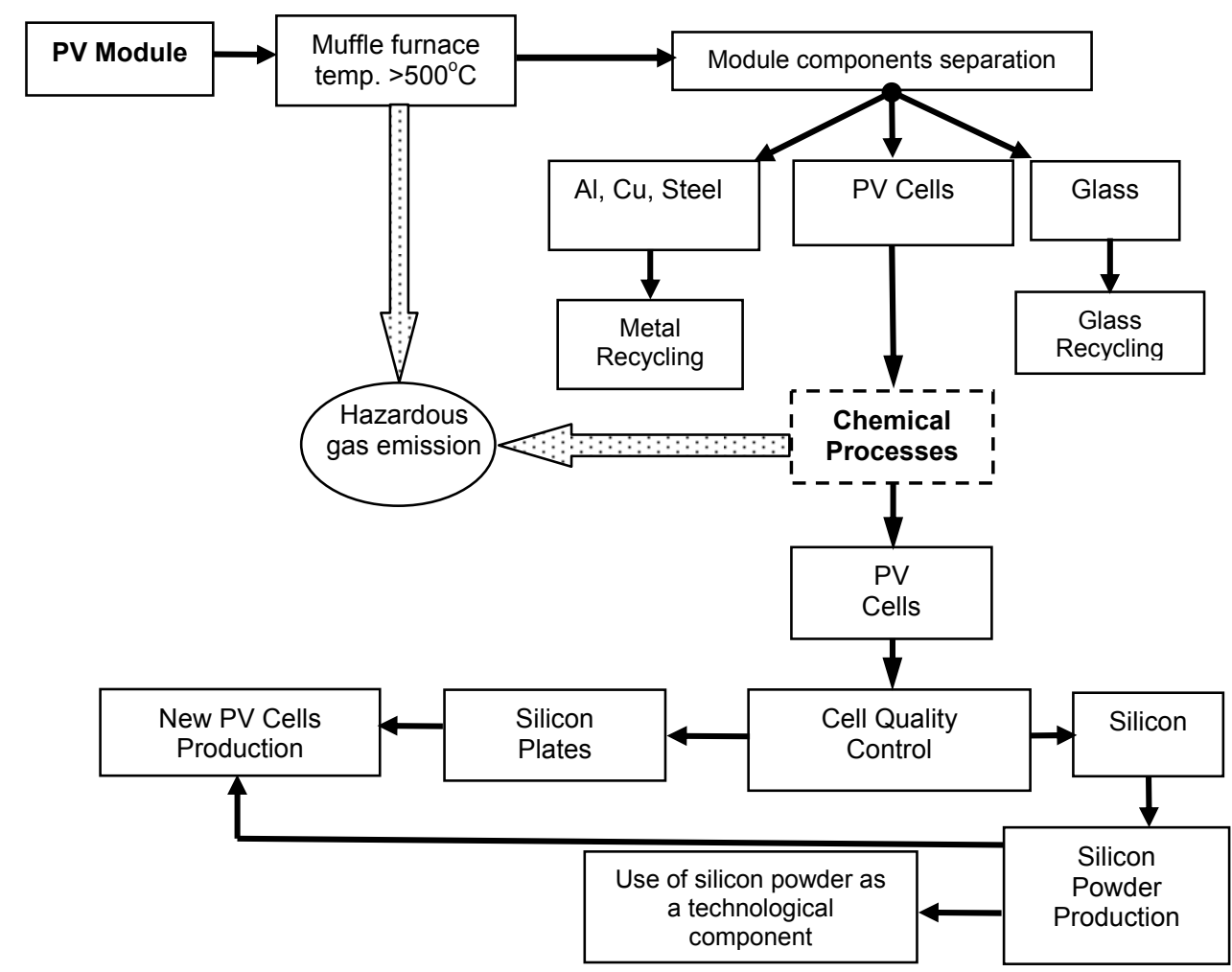

Fig. 1. Thermal and chemical processes in PV crystalline cell and PV module recycling

\section{CHEMICAL ETCHING}

The efficiency of the etching mixtures used in chemical processes of the pure silicon recovering from the recycled PV modules largely depends on the amount and the kind of the pollutants and additions in silicon. Therefore the optimization of the etching processes causes the difficulties in the development of the general technology suitable for the photovoltaic cells from different manufacturers.

Below the specification of some solutions used for silicon etching is presented.

- $\mathrm{HNO}_{3}(70 \%)+\mathrm{HF}(48 \%)(2: 1)$

- $\mathrm{HNO}_{3}(70 \%)+\mathrm{HF}(48 \%)(1: 100)$

- $\mathrm{HNO}_{3}(70 \%)+\mathrm{HF}(48 \%)+\mathrm{C}_{2} \mathrm{H}_{4} \mathrm{O}_{2}+\mathrm{Br}_{2}(250: 150: 150: 3)$ 
- $\mathrm{HNO}_{3}(70 \%)+\mathrm{HF}(48 \%)+\mathrm{C}_{2} \mathrm{H}_{4} \mathrm{O}_{2}(5: 3: 3),(5: 1: 2)$

- $\mathrm{H}_{2} \mathrm{O}_{2}(30 \%)+\mathrm{HF}(48 \%)+\mathrm{H}_{2} \mathrm{O}(1: 1: 4)$

- $\mathrm{H}_{2} \mathrm{SiF}_{6}+\mathrm{HNO}_{3}+\mathrm{C}_{2} \mathrm{H}_{4} \mathrm{O}_{2}(1: 1: 1)$

- $\mathrm{HNO}_{3}(70 \%)+\mathrm{HF}(48 \%)+\mathrm{H}_{2} \mathrm{O}(1: 2: 2)+\mathrm{AgNO}_{3}(1 \mathrm{~g})$.

Some results of the texture etching with the use of $\mathrm{HF} / \mathrm{HNO}_{3} / \mathrm{H}_{2} \mathrm{O}$ solution were presented by Röver at al. [6].

Chemical etching of semiconductors with the use of $\mathrm{HF} / \mathrm{HNO}_{3} / \mathrm{H}_{2} \mathrm{O}$ solution is divided into two steps: oxidation and reduction processes, and then dissolution of the oxidation products connected with the creation of the soluble ions complex. Usually, the causative role of oxidant is fulfilled by the nitric acid $\left(\mathrm{HNO}_{3}\right)$, but the foster agent for the creation of the soluble salts mostly is the hydrofluoric acid (HF). While both of these, mentioned above reactions coincidences in the almost parallel time, they results of a uniform etching, but in case of p-n junction etching (like in case of the silicon recovering from the recycled PV modules) the oxidation and reduction reactions rate should be markedly different. During the silicon etching, a silicofluoric acid $\left(\mathrm{H}_{2} \mathrm{SiF}_{6}\right)$ is produced. It is formed in a formalized two-step-process in the dissolution of silicon in a $\mathrm{HF}-\mathrm{HNO}_{3}$ mixture. In the first step silicon is formally oxidized by $\mathrm{HNO}_{3}$ to $\mathrm{SiO}_{2}$. In the second step, the oxide reacts with $\mathrm{HF}$ to $\mathrm{SiF}_{4}$ that is complexed in excess of $\mathrm{HF}$ as $\mathrm{SiF}_{6}{ }^{2-}$. The total reaction is written as follows (Eq. (1) [5]:

$$
3 \mathrm{Si}+4 \mathrm{HNO}_{3}+18 \mathrm{HF} \rightarrow 3 \mathrm{H}_{2} \mathrm{SiF}_{6}+4 \mathrm{NO}+8 \mathrm{H}_{2} \mathrm{O} .
$$

Selectivity degree and the etching rate are the functions of crystallographic orientation, surface and volumetric structural defects in the silicone and the temperature of etching mixture (Fig.2), as well as hydrodynamics of boundary layer between mixture and semiconductor, too. The temperature has influence on the etching rate this dependence is exponential. Etching process could be limited by the chemical reaction rate or by the diffusion rate of the etching mixture through the surface layer of semiconductor.

Mixing of the etching mixture accelerates the etching process and favorably affects on the uniform dissolution.

Most of the etching mixtures contain hydrofluoric acid (HF) as the oxidation products solvent and nitric acid $\left(\mathrm{HNO}_{3}\right)$ as the oxidation agent.

The two processes are accompanying the semiconductor's surface etching:

- transport of the etching mixture reaction products from and to the etched module surface,

- chemical reaction on the semiconductor surface.

Etching processes should be conducted until the removal of desired layers is reached, whereas it is essential to avoid too great of a loss of silicon. For the silicon base to be proper for the new cells manufacturing, its thickness must not be too small - a loss of mechanical strength may cause that the base will break during the stages of technological processes carried out on its surface. 


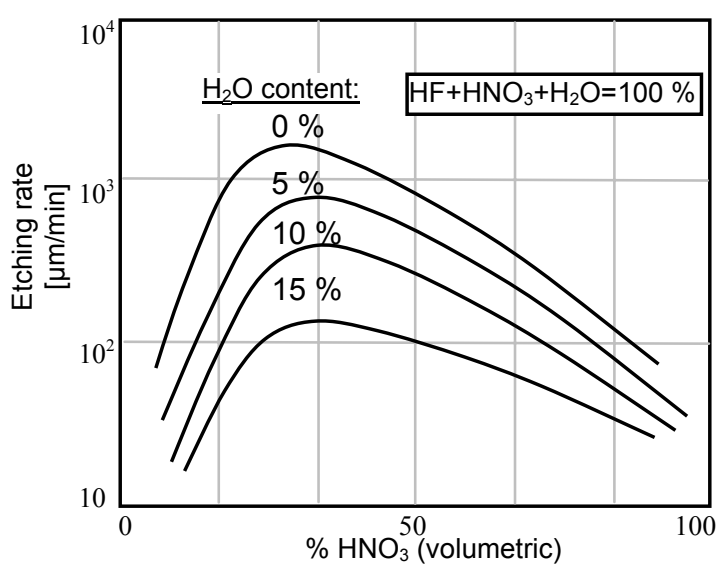

Fig. 2. Etching rate as the function of etching solution composition [2]

\section{EXPERIMENTAL RESULTS}

Chemical etching with use of $\mathrm{KOH}$ water solution with concentration of $40 \mathrm{wt} . \%$ was carried out in order to remove the metallization and electrical contacts from the recycled cells. The Teflon container with etching bath was immersed in a water bath that had heating elements embedded in the walls and in bottom. The process was carried out at the temperature of $80^{\circ} \mathrm{C}$. Antireflective coating with n-p junction then was removed with the use of the mixture $\mathrm{HF}: \mathrm{C}_{2} \mathrm{H}_{4} \mathrm{O}_{2}: \mathrm{HNO}_{3}(1: 2: 5)$.

Two types of mixtures: $\mathrm{H}_{2} \mathrm{SiF}_{6} / \mathrm{HNO}_{3} / \mathrm{C}_{2} \mathrm{H}_{4} \mathrm{O}_{2}$ and $\mathrm{H}_{2} \mathrm{SiF}_{6} / \mathrm{HNO}_{3} / \mathrm{H}_{2} \mathrm{O}$ have been tested for ARC and n-p junction removal. Strong rinse in deionised water is required after the etching process.

In the Fig. 3 a change in etching rate of consecutive layers in the function of temperature for two mixtures: $\mathrm{H}_{2} \mathrm{SiF}_{6} / \mathrm{HNO}_{3} / \mathrm{H}_{2} \mathrm{O}$ and $\mathrm{H}_{2} \mathrm{SiF}_{6} / \mathrm{HNO}_{3} / \mathrm{C}_{2} \mathrm{H}_{4} \mathrm{O}_{2}$ is presented in comparison with the results obtained by Wolf [2].

The process of removing the $n-p$ semiconductor junction was carried out until the dissolution of diffusion layer occurred, with simultaneous examination of resistivity with the use of the four-point probe. Resistivity of a semiconducting material, which is a direct function of dopant concentration, is one of the basic parameters characterizing silicon PV cell bases, allowing the determination of: doping agent's concentration in the base, homogeneity of dopant's surface concentration, depth of the n-p junction and distribution of dopant concentration in different layers.

Next, the etched cells were examined with the use of the metallographic microscope. Microscopic analysis was carried out with the use of microscope Leica Reichert MEF4M with dual reflex module, a beam splitter prism and TV CCD camera for digital images acquisition and computer image analysis (MultiScan Software ${ }^{\circledR}$ ) (Fig. 4, 6, 7) [4]. This optical microscope is an inverted wide field Metallograph with a high degree of automation. It is equipped with the IMIX (Integrated Microanalyzer for Images and $\mathrm{X}$-rays) software for image analysis and offers versatility in the following techniques: Bright Field Imaging, Differential Interference Contrast, Digital Image Acquisition, Field Imaging, Interferometry, Polarized Light and Polarization Contras 


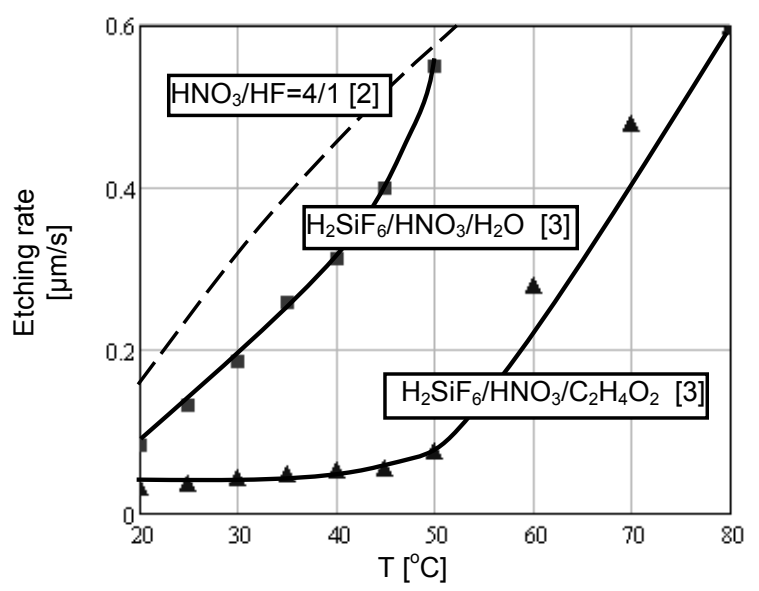

Fig. 3. Temperature dependence of etching rate

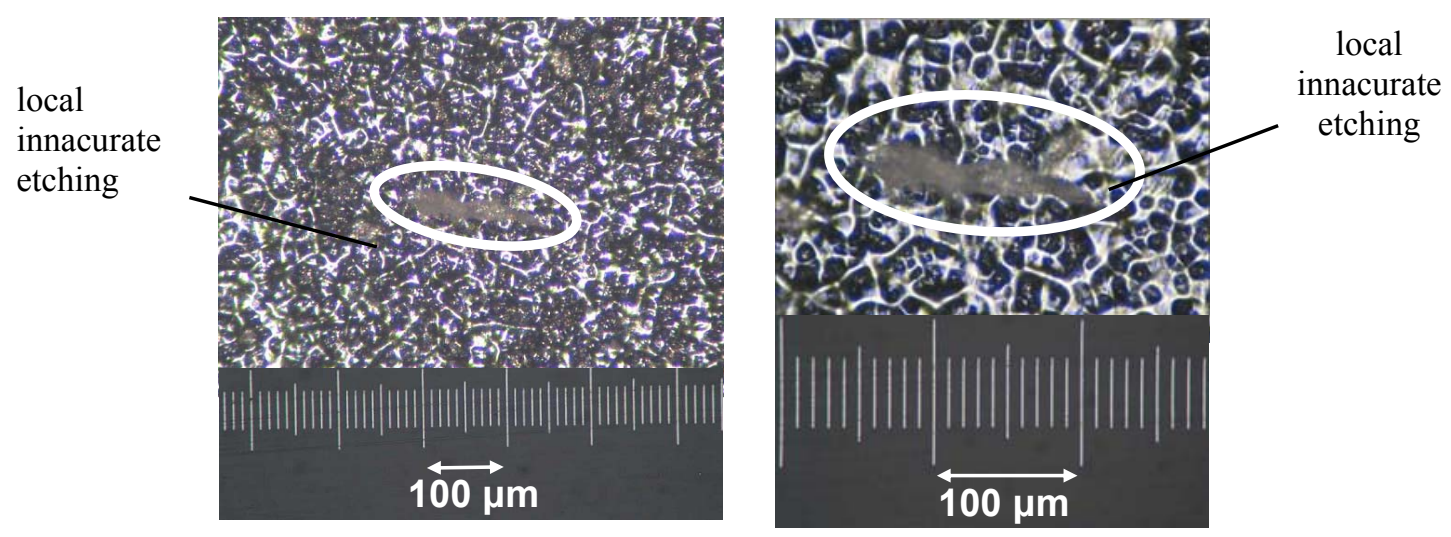

Fig.4. Microscopic view of the back side of the PV cell after etching in $\mathrm{KOH}$
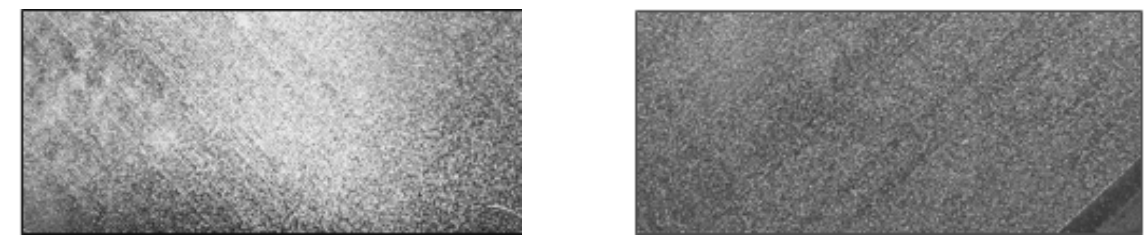

Fig. 5. View of the front and back side of the PV cell after etching in the solution $\mathrm{HF}: \mathrm{C}_{2} \mathrm{H}_{4} \mathrm{O}_{2}: \mathrm{HNO}_{3}$
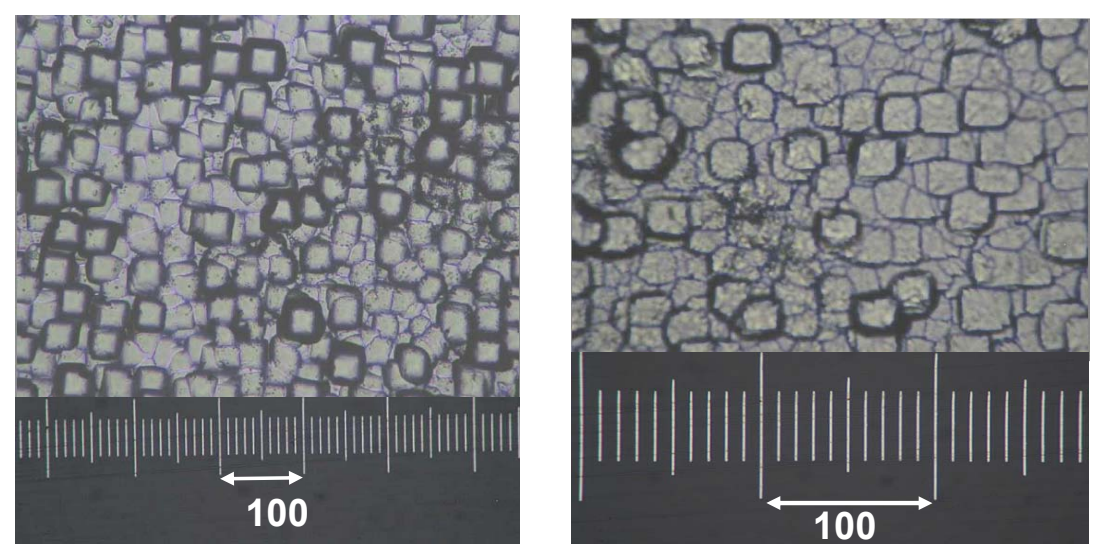

Fig.6. Microscopic view of the etched cell: front and back side of the PV cell 

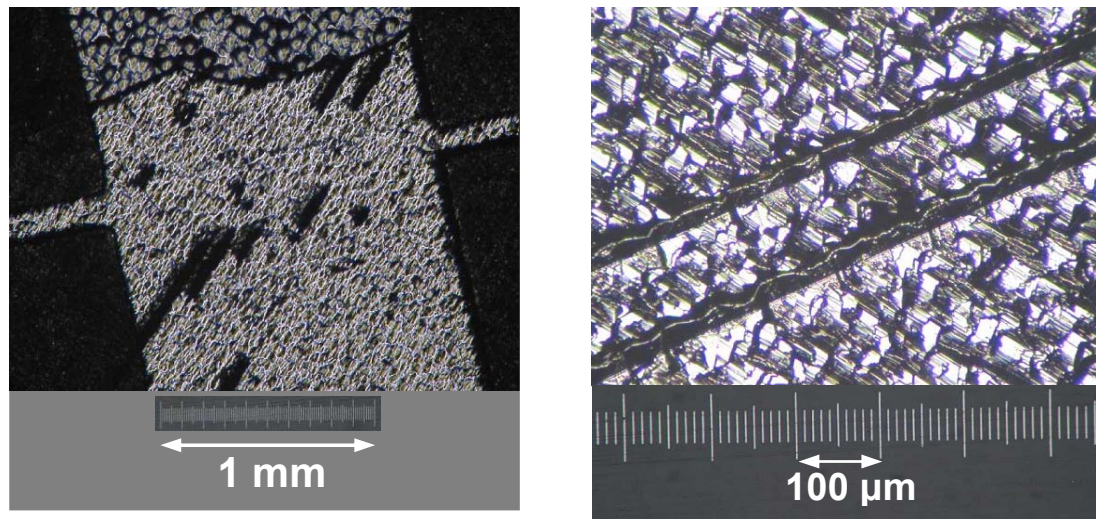

Fig. 7. Polycrystalline structure of the PV cells after etching: $a-$ front side (magnification $25 \times$ ), $b-$ back side (magnification $100 \times$ )

In the Fig. 5 the view of the front and back side of the cell after etching in the solution $\mathrm{HF}: \mathrm{C}_{2} \mathrm{H}_{4} \mathrm{O}_{2}: \mathrm{HNO}_{3}$ are presented.

\section{CONCLUSIONS}

Crystalline silicon type PV modules in the order of mass are composed of: glass, aluminium frame, EVA coating, solar cells, and terminal box, back film, tapping screws. From the economic point of view the pure silicon, which can be recovered from the used cells, is the most important material due to its cost and shortage. For crystalline silicon-based PV cells, the following chemical treatment processes have been conducted: removal of metallization, removal of $\mathrm{ARC}$ and $\mathrm{n}-\mathrm{p}$ junction by etching.

Recycling of the most valuable materials may be applied on the production stage, for on average $5 \%$ of manufactured cells, which do not meet the quality requirements, as well as for cells spent or damaged cells through improper transport, assembly or use.

The compositions of etching solutions were individually adjusted for different silicon cell types. Efforts were taken to formulate a universal etching solution composition, yet the results showed that a solution modification for different types of PV cells is required.

\section{REFERENCES}

1. Wambach K., Schlenker S., Springer J., Konrad B., Sander K., Despotou E., StryiHipp G., PV cycle - on the way to a sustainable and efficient closed loop system for photovoltaics, $22^{\text {nd }}$ European Photovoltaic Solar Energy Conference, Milan, Italy 2007.

2. Müller A., Röver I., Wambach K., von Ramin-Marro D.W., Recovery of high value material of different photovoltaic technologies, 22 ${ }^{\text {nd }}$ European Photovoltaic Solar Energy Conference, 3-7 September, Milan, Italy 2007. 
3. Röver I., Wambach K., Weinreich W., Roewer G., Bohmhammel K., Process Controlling of the Etching System $\mathrm{HF} / \mathrm{HNO}_{3} / \mathrm{H}_{2} \mathrm{O}, 20^{\text {th }}$ European Photovoltaic Solar Energy Conference 2005, Barcelona, Spain.

4. Acker J., Henßge A., Chemical analysis of acidic silicon etch solutions II. Determination of $\mathrm{HNO}_{3}, \mathrm{HF}$, and $\mathrm{H}_{2} \mathrm{SiF}_{6}$ by ion chromatography, Talanta 72 (2007), pp. $1540-1545$

5. Wolf H.F., Semiconductors, WNT Warszawa 1975.

6. Radziemska E., Ostrowski P., Seramak T., Obróbka chemiczna krzemowych ogniw słonecznych jako najważniejszy etap w recyklingu modułów fotowoltaicznych, Środkowoeuropejska Konferencja Substancje Chemiczne w Środowisku Przyrodniczym ECOpole, Piechowice 2008, pp. 1-9.

7. Radziemska E., Lipiński M., Ostrowski P., Re-use of photovoltaic crystalline silicon solar cells - technological possibilities, XII International Symposium Heat Transfer and Renewable Sources of Energy 2008, pp. 187-194. 